\title{
PERSONAL NEED FOR STRUCTURE AND CONTROL MOTIVATION: LINKING SOCIAL COGNITION AND INTERPERSONAL MOTIVATION
}

\author{
Tomáš SOLLÁR, Jana TURZÁKOVÁ \\ Institute of Applied Psychology, Faculty of Social Sciences and Health Care \\ Constantine the Philosopher University in Nitra \\ Kraskova 1, 94974 Nitra, Slovak Republic \\ E-mail: tsollar@ukf.sk, jturzakova@ukf.sk
}

\begin{abstract}
The authors examined the assumption that Personal need for structure (PNS) is negatively related to the approach component of control motivation and positively related to the avoidance component of control motivation. Participants ( $\mathrm{n}=60$ university students) were administered self-report Personal Need for Structure scale and semi-projective Multi-Motive Grid. Analysis showed that PNS was positively related to Fear of Losing Control. No relation between PNS and Hope for Control was found. Results are interpreted in the context of dispositional and situational conditions influencing control motivation.
\end{abstract}

Key words: personal need for structure, control motivation, hope for control, fear of losing control

\section{INTRODUCTION}

Attention and subsequent information processing are selective, especially in case of social stimuli, and determined by our goals (Neuberg et al., 2005). Cognitive processes and motives do not operate in isolation, but rather work together to determine decisionmaking (Roets, Van Hiel, 2011) or behavior generally (e.g., Burger, 1993). Major theories of social-cognitive revolution addressing motivational influences on cognition deal with the effect of epistemic goals on information processing (Fiske, Neuberg, 1990;

This paper was supported by a grant APVV-054012 Psychometric quality of psychodiagnostic measures in career counseling.
Kruglanski, 1989; Cacioppo, Petty, 1982; BarTal, 1994), while research on other fundamental motives is rare (Neuberg et al., 2005).

One of the personality and cognitive constructs addressing the issue of epistemic motivation and cognition is personal need for structure (PNS, Neuberg, Newsom, 1993; Sarmány-Schuller, 2001). People differ in the way they cognitively approach the world some people prefer a clear and simple structure, others appreciate complex information. Personal need for structure is a construct indicating how much organization people prefer to have in their lives (Neuberg, Newsom, 1993). The tendency to reduce information quantity and complexity has its implications for various aspects of psychological functioning, especially social information processing and social interaction.

DOI: $10.21909 /$ sp.2014.03.661 
Individuals high in PNS tend to arrange their social interactions in ways that enable them to avoid complexity, they prefer predictable and scripted social situations with stable and clear rules (Neuberg, Newsom, 1993). They are also more likely to use stereotypes and previously acquired categories in new situations and form less complex representations of the self and the others. Once an answer is found, they are more likely to freeze on the first available explanation and are less likely to search for alternatives (Neuberg, Newsom, 1993). In attribution processes, high PNS individuals tend to attribute the performance of other people to internal causes rather than external constraints such as task difficulty (Schaller et al., 1995) and are more likely to form spontaneous trait inferences when categorizing behavior than those who are low in PNS (Moskowitz, 1993). In context of a working environment, Slijkhuis et al. (2013) showed that high PNS individuals tend to welcome any type of evaluation situations, whereas in low PNS individuals only informational (not controlling) feedback had positive effect on motivation and creative performance. Whereas authors believe desire for simple structure is a fundamental motive, they suggest there is a need for integration of more potentially dispositional motives, especially interpersonal (Neuberg, Newsom, 1993; Sollár, 2008).

From the two basic interpersonal motives clusters - agency and relatedness - we focus on the approach and avoidance dichotomy of control motivation - hope for control and fear of losing control. Control motivation is one of the most pervasive motives determining human behavior. People are motivated to have an impact on their environment, being agents of change, affect the reality - to be a subject as opposed to be an object (Dépret, Fiske, 1993). A substantial domain of the ability to affect the environment is the interpersonal control or social influence. Control motivation is relevant in situations that involve hierarchical social structures - when there are opportunities for influencing and controlling other people's behavior (Sokolowski et al., 2000).

Although the origins of research on control motivation and social cognition can be dated more than a half century ago with works on the authoritarian personality (Adorno et al., 1950), research attention has been directed rather to attitudes and prejudices than to interpersonal motivation, with dominance studied mostly as a part of multidimensional constructs (Jost et al., 2003). Both classical and current works on asymmetric dependence between individuals provide evidence that people in different hierarchical social situations employ different strategies of social cognition. People who already had achieved high power engage in more abstract mental representation (Magee, Smith, 2013). Perceived psychological distance increases the tendency for perceivers to draw spontaneous trait inferences from behavioral information (Rim et al., 2009). High-power individuals do not depend on others and therefore do not need to seek socially relevant information (Dépret, Fiske, 1993) and more often tend to stereotype others in a mutually reinforcing interaction of power and stereotyping (Fiske, 1993). On the other side, people with high control motivation in an effort to enhance prediction and control tend to seek information relevant for action and employ more flexible cognitive strategies. Intensified information processing was found in people who experienced the inability to control their situation (e.g., Pittman, D’Agostino, 1985; Zhou et al., 2012). 


\section{THE PRESENT STUDY}

The aim of the study is to examine relationship between social cognitive construct - PNS and interpersonal motivation construct - control motivation, with regard to its approach and avoidance components. We hypothesize that people low in PNS employ more flexible cognitive strategies which enable them to fulfill approach control motivation needs and therefore tend to score high in hope for control. On the other side, we expect people high in PNS to tend to experience more uncertainty in unpredictable and ambiguous situations and score high in fear of losing control (avoidance tendency).

\section{METHOD}

\section{Design, Participants and Procedure}

We employed correlational research design to investigate the relationship of PNS and control motivation. A sample of university students ( $\mathrm{n}=60$ social sciences students) with mean age 20.7 years $(\mathrm{SD}=1.18$, range 19-24) completed the measures within a general battery of tests.

\section{Measures}

Personal Need for Structure: To measure PNS we employed the Personal Need for Structure Scale (PNS, Thompson et al., 2001; Slovak version by Sarmány Schuller). PNS scale is a 12-item, 6-point Likert-type self-report scale consisting of two subscales Desire for Structure (DS, $\alpha=0.829)$ and Reaction to Lack of Structure (RLS, $\alpha=0.675$ ). Based on previous findings (Neuberg,
Newsom, 1993; Sollár, 2005), item 5 was excluded as both conceptually and empirically incongruous.

Multi-Motive Grid: To measure approach and avoidance components of control motivation we employed the Multi-Motive Grid (MMG, Sokolowski et al., 2000), a semi-projective measure that combines the aspects of the Thematic Apperception Test (TAT) and questionnaires to assess motives regarding performance, control and social acceptance. For each motive, the approach avoidance dichotomy is addressed by separate subscales of hope motives and fear motives. The test contains 18 pictures depicting a set of ambiguous situations linked to performance, control and social acceptance accompanied by 8 statements that represent various motivational states. The respondent indicates his/her answer on a bipolar scale (yes/no).

\section{RESULTS}

To verify the relationship of PNS and control motivation we correlated their subscale and summary scores (the Pearson productmoment correlation coefficient was used). We found a statistically significant correlation of both PNS subscales scores, PNS summary score and Fear of Losing Control, but no relationship of PNS and Hope for Control was found.

In the next step we employed a procedure to transform Hope for Control and Fear of Losing Control scores into standardized z-scores of approach and avoidance to identify the dominant tendency (as recommended by Sokolowski et al., 2000). Analysis of differences did not show the expected results (the Independent Samples t-test was used). 
Table 1. Correlations of PNS subscales, Hope for Control and Fear of Losing Control

\begin{tabular}{|c|c|c|c|c|}
\hline & & PNS RLS & PNS DS & PNS \\
\hline \multirow{3}{*}{ Hope for Control } & $\mathrm{r}$ & -.026 & .102 & .041 \\
\hline & $\mathrm{p}$ & .846 & .438 & .753 \\
\hline & $\mathrm{n}$ & 60 & 60 & 60 \\
\hline \multirow{3}{*}{ Fear of Losing Control } & $\mathrm{r}$ & $280^{*}$ & $301^{*}$ & $.329^{*}$ \\
\hline & $\mathrm{p}$ & .030 & .019 & .010 \\
\hline & $\mathrm{n}$ & 60 & 60 & 60 \\
\hline
\end{tabular}

Table 2. Differences in PNS in participants with approach/avoidance tendency in control motivation

\begin{tabular}{|l|l|c|c|c|c|c|c|}
\hline \multicolumn{2}{|c|}{} & $\mathrm{n}$ & $\mathrm{AM}$ & $\mathrm{SD}$ & $\mathrm{t}$ & $\mathrm{df}$ & $\mathrm{p}$ \\
\hline \multirow{2}{*}{ PNS_RLS } & approach & 28 & 22.18 & 4.53 & \multirow{2}{*}{1.091} & \multirow{2}{*}{58} & \multirow{2}{*}{.280} \\
\cline { 2 - 9 } & avoidance & 32 & 23.50 & 4.81 & & & \\
\hline \multirow{2}{*}{ PNS_DS } & approach & 28 & 13.86 & 3.92 & \multirow{2}{*}{0.664} & \multirow{2}{*}{58} & \multirow{2}{*}{.509} \\
\cline { 2 - 9 } & avoidance & 32 & 14.63 & 4.89 & & \\
\hline \multirow{2}{*}{ PNS } & approach & 28 & 36.04 & 7.62 & \multirow{2}{*}{1.003} & \multirow{2}{*}{58} & \multirow{2}{*}{.320} \\
\cline { 2 - 6 } & avoidance & 32 & 38.13 & 8.40 & &
\end{tabular}

\section{DISCUSSION}

The present study was designed to examine the relationship of PNS and approach avoidance motives of control motivation in interpersonal relationships. We found that PNS is related to the avoidance component of control motive - people high in PNS score high in Fear of Losing Control. They experience fear in situations when distribution of power is ambiguous and potentially about to change. They do not necessarily approach interpersonal situations with control ambitions, as previous findings suggest, e.g., Sollár (2008) found a negative relationship of social dominance orientation as measured by ICL (Leary et al., 1976) and RLS. Trait dominance in Leary's et al. (1976) personality theory can be theoretically considered closer to the approach control component rather than the avoidance control component. That would support the assumption that people try to minimize the conflicting approach - avoidance tendencies, oscillate between the two motives and tend to show either one or the other. Correlations are not strong, but it could be expected since the measures used have a different nature (semiprojective method and self-report method).

At the same time, the analysis showed that PNS is not related to the approach component of control motive. We assume that low PNS itself does not account for the approach control motivation. Active approach strategy in control motivation depends on more complex motivational and cognitive structuring dispositions. Therefore, people can be successful in their control ambitions regardless of high or low PNS, which is one of the dispositions and together with other personal traits (e.g., dominance) and various 
situational variables can result in approach control behavior. We believe that in personally significant situations, when people are highly motivated, different motives and capacities can overcome the influence of dispositional PNS. Therefore, our hypothesis should be revised in terms of taking into account situational valency. Further research is needed to verify our preliminary results in a larger and more general sample and to explore the moderating influence of both dispositional and situational variables responsible for control motivation.

Received February 27, 2014

\section{REFERENCES}

ADORNO T.W., FRENKEL-BRUNSWIK, E., LEVINSON, D.J., SANFORD, R.N., 1950, The authoritarian personality. New York: Harper.

BAR-TAL, Y., 1994, The effect of mundane decision-making of the need and ability to achieve cognitive structure. European Journal of Personality, 8, 45-58.

BURGER, J.M., 1993, Individual differences in control motivation and social information processing. In: G. Weary, F. Gleicher, K.L. Marsh (Eds.), Control Motivation and Social Cognition (pp. 203219). New York: Springer.

CACIOPPO, J.T., PETTY, R.E., 1982, Need for cognition. Journal of Personality and Social Psychology, 42, 1, 116-131.

DÉPRET, E., FISKE, S.T., 1993, Social cognition and power: Some cognitive consequences of social structure as a source of control deprivation. In: G. Weary, F. Gleicher, K.L. Marsh (Eds.), Control Motivation and Social Cognition (pp. 176-202). New York: Springer.

FISKE, S.T., NEUBERG, S.L., 1990, A continuum of impression formation from category-based to individuating processes. Influences of information and motivation on attention and interpretation. In: M.P. Zanna (Ed.), Advances in Experimental Social Psychology, Vol. 23 (pp. 1-74). New York: Academic Press.

FISKE, S.T., 1993, Controlling other people: The impact of power on stereotyping. American Psychologist, 48, 6, 621-628.
JOST, J.T., GLASER, J., KRUGLANSKI, A.W., SULLOWAY, F.J., 2003, Political conservatism as motivated social cognition. Psychological Bulletin, 129, 3, 339-375.

KRUGLANSKI, A.W., 1989, Lay epistemic and human knowledge: Cognitive and motivational bases. New York: Plenum.

LEARY, T., LAFORGE, R.L., SUCZEK, R.F., 1976, Dotazník interpersonální diagnózy ICL. Př́ručka. Upravili J. Kožený, P. Ganický. Bratislava: Psychodiagnostické a didaktické testy.

MAGEE, J.C., SMITH, P.K., 2013, The Social Distance Theory of Power. Personality and Social Psychology Review, 17, 2, 158-186.

MOSKOWITZ, G.B., 1993, Individual differences in social categorization: The influence of personal need for structure on spontaneous trait inferences. Journal of Personality and Social Psychology, 65, 1, 132-142.

NEUBERG, S.L., NEWSOM, J.T., 1993, Personal need for structure: Individual differences in the desire for simple structure. Journal of Personality and Social Psychology, 65, 1, 113-131.

NEUBERG, S.L., KENRICK, D.T., MANER, J.K., SCHALLER, M., 2005, From evolved motives to everyday mentation. Evolution, goals and cognition. In: J.P. Forgas, K.D. Williams, S.M. Laham (Eds.), Social Motivation: Conscious and Unconscious Processes (pp. 133-153). Cambridge: Cambridge University Press.

PITTMAN, T.S., D’AGOSTINO, P.R., 1985, Motivation and attribution: The effects of control deprivation on subsequent information processing. In: J. Harvey, G. Weary (Eds.), Attribution: Basic issues and applications (pp. 117-141). New York: Academic Press.

RIM, S.Y., ULEMAN, J.S., TROPE, Y., 2009, Spontaneous trait inference and construal level theory: Psychological distance increases nonconscious trait thinking. Journal of Experimental Social Psychology, 45, 5, 1088 -1097.

ROETS, A., VAN HIEL, A., 2011, An integrative process approach on judgment and decision making: The impact of arousal, affect, motivation, and cognitive ability. Psychological Record, 61, 3, 497520 .

SARMÁNY-SCHULLER, I., 2001, Potreba štruktúry a schopnost' vytvárania štruktúry ako osobnostné konštrukty. [Need for structure and ability to achieve structure as personality constructs]. In: I. Sarmány-Schuller (Ed.), Psychológia pre bezpečný svet. [Psychology for Safe World] (pp. 336-339). Bratislava: Stimul. 
SCHALLER, M., BOYD, C., YOHANNES, J., O'BRIEN, M., 1995, The prejudiced personality revisited: Personal need for structure and formation of erroneous group stereotypes. Journal of Personality and Social Psychology, 68, 3, 544-555.

SLIJKHUIS, J.M., RIETZSCHEL, E.F., VAN YPEREN, N.W., 2013, How evaluation and need for structure affect motivation and creativity. European Journal of Work and Organizational Psychology, 22, 1, 15-25.

SOKOLOWSKI, K., SCHMALT, H.D., LANGENS, T.A., PUCA, R.M., 2000, Assessing achievement, affiliation, and power motives all at once: The Multi-Motive-Grid (MMG). Journal of Personality Assessment, 74, 1, 126-145.

SOLLÁR, T., 2005, Potreba kognitívnej štruktúry $\mathrm{v}$ kontexte osobnostných a interpersonálnych premenných. Dizertačná práca, Bratislava: UEPs SAV.

SOLLÁR, T., 2008, Need for structure from a theoretical and methodological perspective. Studia Psychologica, 50, 3, 277-289.

THOMPSON, M.M., NACCARATO, M.E., PARKER, K.C.H., MOSKOWITZ, G.B., 2001, The personal need for structure and personal fear of invalidity measures: Historical perspectives, current applications, and future directions. In: G.B. Moskowitz (Ed.), Cognitive social psychology: The Princeton symposium on the legacy and future of social cognition (pp. 19-39). Mahwah, NJ: Erlbaum. ZHOU, X., HE, L., YANG, Q., LAO, J., BAUMEISTER, R.F., 2012, Control deprivation and styles of thinking. Journal of Personality and Social Psychology, 102, 3, 460-478.

\title{
OSOBNÁ POTREBA ŠTRUKTÚRY A KONTROLNÁ MOTIVÁCIA: PREPOJENIE SOCIÁLNYCH KOGNÍCIÍ A INTERPERSONÁLNEJ MOTIVÁCIE
}

\author{
T. S o 11 á r, J. Tu r zá k o vá
}

Súhrn: Autori skúmali predpoklad, že potreba štruktúry (PNS) je v negatívnom vzt’ahu s motiváciou ku kontrole $\mathrm{v}$ zmysle približovania a v pozitívnom vztahu s motiváciou ku kontrole $\mathrm{v}$ zmysle vyhýbania. Participantom ( $\mathrm{n}=60$ univerzitným študentom) bol administrovaný sebavýpoved’ový dotazník Potreba štruktúry (PNS) a semi-projektívny dotazník Multimotivačná mriežka (MMG). Výsledky ukázali, že potreba štruktúry je v pozitívnom vzt’ahu so Strachom zo straty kontroly. Dáta nepodporili predpoklad o negatívnom vzt’ahu potreby štruktúry a Túžbou po kontrole. Výsledky sú interpretované v kontexte dispozičných a situačných podmienok ovplyvňujúcich motiváciu ku kontrole. 